\title{
Comparison of Laboratory Data in Dogs with Heartworm Caval Syndrome Surviving and Nonsurviving after Surgical Treatment
}

\author{
Hitoshi KITAGAWA, Katsuya KITOH, Toshiroh IWASAKI ${ }^{1}$, and Yoshihide SASAKI \\ Laboratory of Internal Medicine, Division of Veterinary Medicine, and ${ }^{l}$ Veterinary Teaching Hospital, Faculty of Agriculture, Gifu \\ University, 1-1 Yanagido, Gifu 501-11, Japan
}

(Received 10 May 1995/Accepted 24 March 1997)

ABSTRACT. Laboratory data in 47 dogs with caval syndrome (CS) surviving after surgical HW removal compared with those in 15 dogs with CS which died after the treatment. The number of HWs removed in surviving dogs was significantly greater than in nonsurviving dogs. The Ht value was significantly higher in nonsurviving dogs than in surviving dogs. Plasma enzyme activities ranged widely from normal to extremely high levels, and there were no significant differences in plasma enzyme activities between the surviving and nonsurviving dogs. Serum total protein, and plasma triglyceride, creatinine, glucose, calcium, sodium (Na) and chloride $(\mathrm{Cl})$ levels were much similar between the HW-free and surviving dogs, but significantly different between the HW-free and nonsurviving dogs. Plasma urea nitrogen, uric acid and potassium levels were higher, and plasma $\mathrm{Na}$ and $\mathrm{Cl}$ levels were lower in nonsurviving dogs than in surviving dogs. - KEY WORDS: canine, caval syndrome, laboratory test result.

J. Vet.Med.Sci. 59(7): 609-611, 1997

Caval syndrome (CS) is a severe manifestation of heartworm (HW) disease. The onset of the disease is sudden, and most dogs die in the acute course when they do not receive adequate treatment $[1,10]$. In dogs with $C S$, tricuspid valve dysfunction with worms at the tricuspid valve orifice, as well as lesions in the pulmonary arteries induced severe circulatory disturbance, and leads to congestive heart failure and other organ malfunction [7]. Measurements of cardiopulmonary function values are valuable, but those are difficult for every dog in veterinary practice. Usually, practitioners use clinical signs and laboratory data, which were reflections of circulatory and organ disturbance, for evaluation of patient dogs. Clinical pathologic data in dogs with CS were reported previously by us [6] and Atwell and Farmer [2]. However, comparison of the data in survived and nonsurvived dogs after surgical HW removal has not been performed. The present study focuses on differences in laboratory data at pre-HW removal between the dogs with CS surviving and died after surgical HW removal.

Fifteen clinically normal and HW-free dogs (HW-free group), which received continuously for HW preventives, and 62 patient dogs with naturally acquired CS visiting the Veterinary Hospital of Gifu University were studied. Fortyseven dogs survived the disease (surviving group), and 15 dogs died or were euthanatized (nonsurviving group) from 2 days to 2 months after surgical treatment. Under general anesthesia, HWs were removed with venotomy using flexible alligator forceps (FK-480L and FK-380S, Fuji Photo Optimal Co., Ltd., Omiya, Japan). After surgical treatment, dogs received antibiotics, diuretics, cardionics, vitamin $\mathrm{B}_{12}$, ferrous medicine and glutathion according to their symptoms. Peripheral blood was collected before anesthesia. The blood cells were counted with an automated cell counter (Celltac MEK-5155, Nihon Kohden Corp., Tokyo). Biochemical tests were performed by dry chemistry (DRI-CHEM 5500V and 800V, Fuji Photo Film Co., Ltd., Tokyo). Variables compared were age and body weight of the dog, number of HWs removed, $\mathrm{RBC}, \mathrm{Ht}, \mathrm{Hb}, \mathrm{WBC}$, alanine aminotransaminase (ALT), creatine kinase (CK), lactate dehydrogenase (LD), alkaline phosphatase (ALP), gamma-glutamyltransferase (GGT), total bilirubin, ammonia, total protein (TP), albumin, $\mathrm{A} / \mathrm{G}$ ratio, trigryceride (TG), total cholesterol (TCHO), urea nitrogen (UN), creatinine (CRE), uric acid (UA), glucose (GLU), calcium $(\mathrm{Ca})$, sodium $(\mathrm{Na})$, potassium $(\mathrm{K})$, and chloride $(\mathrm{Cl})$. Student's $t$-test or Cochran-Cox test and Duncan's new multiple range test were used for comparison of the data between the 2 groups and among the 3 groups, respectively.

As shown in Table 1, there were no significant differences in age and body weight between the surviving and nonsurviving dogs. The number of worms removed from the right atrium and tricuspid valve orifice was greater $(\mathrm{P}<0.01)$ in surviving dogs than in nonsurviving dogs. From

Table 1. Age and body weight of dogs and number of heartworms removed by venotomy in dogs with caval syndrome

\begin{tabular}{|c|c|c|c|}
\hline \multirow[b]{2}{*}{ Variable } & \multicolumn{2}{|r|}{ Group } & \multirow[b]{2}{*}{$\mathrm{P}<$} \\
\hline & $\begin{array}{l}\text { Surviving } \\
(\mathrm{n}=47)\end{array}$ & $\begin{array}{l}\text { Nonsurviving } \\
\quad(\mathrm{n}=15)\end{array}$ & \\
\hline Age (year) & $7.0 \pm 2.9$ & $8.0 \pm 2.5$ & NS \\
\hline Body weight (kg) & $10.7 \pm 5.2$ & $11.6 \pm 3.4$ & NS \\
\hline $\begin{array}{l}\text { No. of worms removed from } \\
\text { right atrium and tricuspid } \\
\text { valve orifice }\end{array}$ & $\begin{array}{l}23.2 \pm 12.9 \\
(1 \text { to } 75)\end{array}$ & $\begin{array}{l}10.3 \pm 12.8 \\
(1 \text { to } 40)\end{array}$ & 0.01 \\
\hline $\begin{array}{l}\text { No. of worms removed from } \\
\text { pulmonary artery }\end{array}$ & $\begin{array}{l}4.7 \pm 12.0 \\
(0 \text { to } 60)\end{array}$ & $\begin{array}{l}0.9 \pm 2.2 \\
(0 \text { to } 7)\end{array}$ & NS \\
\hline $\begin{array}{l}\text { Total No. of worms } \\
\text { removed }\end{array}$ & $\begin{array}{l}27.9 \pm 18.7 \\
(2 \text { to } 90)\end{array}$ & $\begin{array}{l}11.1 \pm 14.0 \\
(1 \text { to } 47)\end{array}$ & 0.01 \\
\hline $\begin{array}{l}\text { Total No. of worms } / \mathrm{kg} \\
\text { body weight }\end{array}$ & $\begin{array}{c}3.27 \pm 3.11 \\
(0.19 \text { to } 13.3)\end{array}$ & $\begin{array}{l}1.40 \pm 2.65 \\
(0.03 \text { to } 9.4)\end{array}$ & 0.05 \\
\hline
\end{tabular}

Data are expressed as mean $\pm \mathrm{SD}$, and range (minimum to maximum). $\mathrm{P}=$ Probability of significant difference between the values in the surviving and nonsurviving groups; NS=not significant. 
Table 2. Hematological test results and plasma enzyme activities in heartworm-free dogs and in dogs with caval syndrome at pre-heartworm removal

\begin{tabular}{|c|c|c|c|}
\hline \multirow[b]{2}{*}{ Variable } & \multicolumn{3}{|c|}{ Group } \\
\hline & $\begin{array}{l}\text { HW-free } \\
(n=15)\end{array}$ & $\begin{array}{l}\text { Surviving } \\
(\mathrm{n}=47)\end{array}$ & $\begin{array}{c}\text { Nonsurviving } \\
(\mathrm{n}=15)\end{array}$ \\
\hline $\operatorname{RBC}\left(10^{3} / \mu l\right)$ & $\begin{array}{c}7,800 \pm 1,360 \\
(6,090 \text { to } 9,890)\end{array}$ & $\begin{array}{l}4,750 \pm 1,860^{*} \\
(1,870 \text { to } 8,920)\end{array}$ & $\begin{array}{c}5,710 \pm 1,471^{* \dagger} \\
(2,940 \text { to } 8,850)\end{array}$ \\
\hline $\mathrm{Ht}(\%)$ & $\begin{array}{c}51.0 \pm 5.5 \\
(41.0 \text { to } 59.0)\end{array}$ & $\begin{array}{c}30.5 \pm 9.1^{*} \\
(14.0 \text { to } 53.0)\end{array}$ & $\begin{array}{c}35.7 \pm 7.8^{* \dagger} \\
(22.0 \text { to } 50.0)\end{array}$ \\
\hline $\mathrm{Hb}(\mathrm{g} / \mathrm{d} l)$ & $\begin{array}{c}16.9 \pm 2.6 \\
(12.4 \text { to } 20.0)\end{array}$ & $\begin{array}{c}9.3 \pm 3.1^{*} \\
(3.9 \text { to } 18.8)\end{array}$ & $\begin{array}{l}11.0 \pm 3.2^{*} \\
(6.2 \text { to } 19.0)\end{array}$ \\
\hline $\mathrm{WBC}\left(10^{3} / \mu l\right)$ & $\begin{array}{c}11.3 \pm 2.9 \\
(6.9 \text { to } 16.2)\end{array}$ & $\begin{array}{l}20.9 \pm 9.6^{*} \\
\text { (7.2 to } 56.8)\end{array}$ & $\begin{array}{r}24.9 \pm 9.5^{*} \\
(12.3 \text { to } 42.9)\end{array}$ \\
\hline $\begin{array}{l}\text { Alanine trans- } \\
\text { aminase (IU/l) }\end{array}$ & $\begin{array}{c}38 \pm 13 \\
(18 \text { to } 59)\end{array}$ & $\begin{array}{l}245 \pm 396^{*} \\
(11 \text { to } 2364)\end{array}$ & $\begin{array}{l}252 \pm 318^{*} \\
(33 \text { to } 970 \text { ) }\end{array}$ \\
\hline $\begin{array}{l}\text { Creatine kinase } \\
\text { (IU/l) }\end{array}$ & $\begin{array}{c}101 \pm 37 \\
(50 \text { to } 181)\end{array}$ & $\begin{array}{l}397 \pm 304^{*} \\
(57 \text { to } 1492)\end{array}$ & $\begin{array}{l}432 \pm 423^{*} \\
\text { (93 to } 1573 \text { ) }\end{array}$ \\
\hline $\begin{array}{l}\text { Lactate dehydro- } \\
\text { genase (IU/l) }\end{array}$ & $\begin{array}{c}75 \pm 53 \\
\text { (31 to } 217)\end{array}$ & $\begin{array}{l}355 \pm 249^{*} \\
(56 \text { to } 984)\end{array}$ & $\begin{array}{r}208 \pm 123^{*}+ \\
(55 \text { to } 438)\end{array}$ \\
\hline $\begin{array}{l}\text { Alkaline phospha- } \\
\text { tase (IU/l) }\end{array}$ & $\begin{array}{l}\text { a- } 79 \pm 42 \\
\quad(3 \text { to } 147)\end{array}$ & $\begin{array}{c}268 \pm 236^{*} \\
\text { (9 to } 941 \text { ) }\end{array}$ & $\begin{array}{l}443 \pm 612^{*} \\
(9 \text { to } 2544)\end{array}$ \\
\hline $\begin{array}{l}\text { Gamma-glutamyl- } \\
\text { tansferase }{ }^{\#} \text { (IU/l) }\end{array}$ & $\begin{array}{l}1.5 \pm 1.2 \\
(1 \text { to } 5)\end{array}$ & $\begin{array}{l}2.4 \pm 6.7 \\
(0 \text { to } 43)\end{array}$ & $\begin{array}{c}6.1 \pm 16.3 \\
(0 \text { to } 62)\end{array}$ \\
\hline
\end{tabular}

Data are expressed as mean $\pm \mathrm{SD}$ and range (minimum to maximum). *Significantly $(\mathrm{P}<0.01)$ different from the value in the HW-free group. ${ }^{\dagger}$ Significantly different from the value in the surviving group. $\mathrm{HW}=$ Heartworm. "Number of dogs in surviving and nonsurviving group are 43 and 14 , respectively.

the pulmonary arteries, HWs could be removed in 25 of 47 surviving dogs and 4 of 15 nonsurviving dogs. The total number of worms removed was significantly $(\mathrm{P}<0.01)$ greater in surviving dogs than in nonsurviving ones. Also, the total number of worms per $\mathrm{kg}$ body weight of the dog was greater $(\mathrm{P}<0.05)$ in surviving dogs.

Table 2 shows the hematological test results and plasma enzyme activities. The RBC count and Ht value were significantly higher in nonsurviving dogs than in surviving dogs. Plasma enzyme activities ranged widely from normal to extremely high levels, and tended to be higher in dogs with CS. Plasma LDH level was lower in nonsurviving dogs, and there were no significant differences in plasma ALT, CK, ALP, and GGT activities between the surviving and nonsurviving groups.

Table 3 shows the biochemical test results. Plasma TCHO concentrations was not different among the 3 groups. Serum TP, and plasma TG, CRE, GLU, Ca, $\mathrm{Na}$ and $\mathrm{Cl}$ levels were much similar between the $\mathrm{HW}$-free and surviving groups, but significantly different between the HW-free and nonsurviving group. Plasma UN, UA and K levels were higher, and plasma $\mathrm{Na}$ and $\mathrm{Cl}$ levels were lower
Table 3. Biochemical test results in heartworm-free dogs and in dogs with caval syndrome at pre-heartworm removal

\begin{tabular}{|c|c|c|c|}
\hline \multirow[b]{2}{*}{ Variable } & \multicolumn{3}{|c|}{ Group } \\
\hline & $\begin{array}{c}\text { HW-free } \\
(\mathrm{n}=15)\end{array}$ & $\begin{array}{c}\text { Surviving } \\
(\mathrm{n}=47)\end{array}$ & $\begin{array}{c}\text { Nonsurviving } \\
\quad(\mathrm{n}=15)\end{array}$ \\
\hline $\begin{array}{l}\text { Total bilirubin } \\
(\mathrm{mg} / \mathrm{d} l)\end{array}$ & $\begin{array}{c}0.4 \pm 0.2 \\
(0.2 \text { to } 0.9)\end{array}$ & $\begin{array}{c}1.2 \pm 1.2^{*} \\
(0.1 \text { to } 7.0)\end{array}$ & $\begin{array}{l}1.0 \pm 0.8^{*} \\
(0.3 \text { to } 2.8)\end{array}$ \\
\hline Ammonia $(\mu \mathrm{g} / \mathrm{d} l)$ & $\begin{array}{c}29 \pm 7 \\
(19 \text { to } 44)\end{array}$ & $\begin{array}{c}85 \pm 60^{*} \\
\text { (16 to } 285)\end{array}$ & $\begin{array}{l}112 \pm 71^{*} \\
\text { (16 to } 300)\end{array}$ \\
\hline Total protein $(\mathrm{g} / \mathrm{d} l)$ & $\begin{array}{c}6.0 \pm 0.6 \\
(5.1 \text { to } 7.2)\end{array}$ & $\begin{array}{c}6.3 \pm 1.2 \\
(3.5 \text { to } 9.9)\end{array}$ & $\begin{array}{l}5.5 \pm 1.1^{*} \\
(3.8 \text { to } 8.5)\end{array}$ \\
\hline Albumin $(\mathrm{g} / \mathrm{d} l)$ & $\begin{array}{c}3.1 \pm 0.3 \\
(2.7 \text { to } 3.9)\end{array}$ & $\begin{array}{c}2.5 \pm 0.5^{*} \\
(1.6 \text { to } 3.7)\end{array}$ & $\begin{array}{l}2.4 \pm 0.5^{*} \\
(1.7 \text { to } 3.3)\end{array}$ \\
\hline $\mathrm{A} / \mathrm{G}$ ratio & $\begin{array}{l}1.10 \pm 0.15 \\
(2.7 \text { to } 3.9)\end{array}$ & $\begin{array}{c}0.71 \pm 0.17^{*} \\
(0.33 \text { to } 1.06)\end{array}$ & $\begin{array}{c}0.82 \pm 0.25 \\
(0.37 \text { to } 1.24)\end{array}$ \\
\hline $\begin{array}{l}\text { Triglyceride } \\
(\mathrm{mg} / \mathrm{d} l)\end{array}$ & $\begin{array}{c}61 \pm 30 \\
(25 \text { to } 144)\end{array}$ & $\begin{array}{c}70 \pm 20 \\
\text { (35 to } 127)\end{array}$ & $\begin{array}{c}80 \pm 28^{*} \\
\text { (52 to } 156)\end{array}$ \\
\hline $\begin{array}{l}\text { Total cholesterol } \\
(\mathrm{mg} / \mathrm{d} l)\end{array}$ & $\begin{array}{c}180 \pm 58 \\
(92 \text { to } 303)\end{array}$ & $\begin{array}{c}172 \pm 66 \\
\text { (88 to } 429)\end{array}$ & $\begin{array}{c}181 \pm 58 \\
\text { (74 to } 305 \text { ) }\end{array}$ \\
\hline $\begin{array}{l}\text { Urea nitrogen } \\
(\mathrm{mg} / \mathrm{d} l)\end{array}$ & $\begin{array}{c}16 \pm 5 \\
\text { (5 to } 23)\end{array}$ & $\begin{array}{l}40 \pm 29 * \\
(7 \text { to } 123)\end{array}$ & $\begin{array}{l}70 \pm 52^{*} \dagger \\
\text { (17 to } 200 \text { ) }\end{array}$ \\
\hline Creatinine $(\mathrm{mg} / \mathrm{d} l)$ & $\begin{array}{c}0.9 \pm 0.2 \\
(0.5 \text { to } 1.4)\end{array}$ & $\begin{array}{c}1.5 \pm 1.0 \\
(0.4 \text { to } 6.7)\end{array}$ & $\begin{array}{l}2.0 \pm 2.1 * \\
(0.4 \text { to } 9.1)\end{array}$ \\
\hline Uric $\operatorname{acid}^{\#}(\mathrm{mg} / \mathrm{d} l)$ & $\begin{array}{c}0.3 \pm 0.1 \\
(0.2 \text { to } 0.4)\end{array}$ & $\begin{array}{c}0.7 \pm 0.4 \\
(0.2 \text { to } 2.8)\end{array}$ & $\begin{array}{l}1.0 \pm 0.6^{* \dagger} \\
(0.4 \text { to } 2.5)\end{array}$ \\
\hline Glucose $(\mathrm{mg} / \mathrm{d} l)$ & $\begin{array}{c}93 \pm 15 \\
(72 \text { to } 134)\end{array}$ & $\begin{array}{c}100 \pm 23 \\
\text { (57 to } 155)\end{array}$ & $\begin{array}{l}113 \pm 18^{*} \\
\text { (23 to } 154)\end{array}$ \\
\hline Calcium $(\mathrm{mg} / \mathrm{d} l)$ & $\begin{array}{c}11.2 \pm 0.6 \\
(10.1 \text { to } 12.3)\end{array}$ & $\begin{array}{c}11.1 \pm 0.9 \\
(9.4 \text { to } 12.9)\end{array}$ & $\begin{array}{l}10.6 \pm 1.2^{*} \\
\text { (8.6 to } 13.3 \text { ) }\end{array}$ \\
\hline $\mathrm{Na}(\mathrm{mmol} / \mathrm{l})$ & $\begin{array}{c}145 \pm 3.1 \\
(138 \text { to } 152)\end{array}$ & $\begin{array}{c}140 \pm 8.7 \\
(94 \text { to } 150)\end{array}$ & $\begin{array}{l}137 \pm 6.9^{* \dagger} \\
(121 \text { to } 146)\end{array}$ \\
\hline $\mathrm{K}(\mathrm{mmol} / \mathrm{l})$ & $\begin{array}{c}3.7 \pm 0.3 \\
(3.3 \text { to } 4.3)\end{array}$ & $\begin{array}{l}4.1 \pm 0.6^{*} \\
(2.8 \text { to } 5.5)\end{array}$ & $\begin{array}{l}4.9 \pm 0.8 * \dagger \\
\text { (3.9 to } 6.8)\end{array}$ \\
\hline $\mathrm{Cl}(\mathrm{mmol} / \mathrm{l})$ & $\begin{array}{c}109 \pm 3 \\
(104 \text { to } 113)\end{array}$ & $\begin{array}{c}107 \pm 6 \\
(86 \text { to } 119)\end{array}$ & $\begin{array}{l}102 \pm 6^{* \dagger} \\
(88 \text { to } 112)\end{array}$ \\
\hline
\end{tabular}

Data are expressed as mean $\pm \mathrm{SD}$, and range (minimum to maximum). * Significantly $(\mathrm{P}<0.01)$ different from the value in the HW-free group. ${ }^{\dagger}$ Significantly different from the value in the surviving group. $\mathrm{HW}=$ Heartworm. "Number of dogs in surviving and nonsurviving group are 44 and 14 , respectively.

in nonsurviving dogs than in surviving dogs.

Nonsurviving dogs had a significantly fewer adult HWs removed. As shown in our previous study [7], nonsurviving dogs with CS had small number of worms residing, high pulmonary arterial pressure and dilated pulmonary arterial trunk. These might relate with more severe pulmonary thromboembolism from dead HWs and more severe 
circulatory disturbance. Although the laboratory data examined overlapped, almost all variables showed abnormalities in dogs with CS, and suggested the multiple organ dysfunction secondary from circulatory disturbance. The higher plasma TG concentration might relate with an increase in plasma low density lipoprotein following liver dysfunction [8]. Higher plasma UN and its precursor (ammonia) concentrations suggested more severe tissue destruction and delay of removal from circulation by the liver [1]. Significantly higher plasma UN, CRE, UA and K levels and lower plasma $\mathrm{Na}$ and $\mathrm{Cl}$ levels in nonsurviving dogs than in surviving dogs might result from more severe liver dysfunction, and metabolic acidosis, as well as intravascular hemolysis [3-5, 9]. These variables also associated closely with renal function. Renal function might be one of the important parameters indicating prognosis of the dog. Also in our clinical experiences, nonsurviving dogs with CS tended to have renal failure.

Most dogs with CS show acute disease course, and signs of severe anemia, liver injury, renal dysfunction, cardiac congestion and intravascular hemolysis $[1,2,6,10]$. Also in the present study, most dogs had the laboratory data indicated severe multiple organ malfunction. Besides, some dogs show chronic signs of HW disease such as long-term ascites, exercise intolerance and labored respiration. These dogs tended to harbor a smaller number of live adult HWs and to have a higher pulmonary arterial pressure [7], mildly higher plasma enzyme activities, and an unclear hemoglobinuria. These facts suggested that dogs with CS involved various stages, with almost normal to severely disturbed circulation. Surgical HW removal was effective as the treatment of choice for most dogs with CS, but might not be effective in dogs with chronic type of CS.

\section{REFERENCES}

1. Atwell, R. B. and Buoro, I. B. J. 1988. pp. 191-203. In: Dirofilariasis (Boreham, P. F. L. and Atwell, R. B. eds.), CRC Press, Boca Raton.

2. Atwell, R. B. and Farmer, T. S. 1982. Small Anim. Pract. 23: 675-685.

3. Capen, C. C. and Rosol, T. J. 1989. pp. 678-752. In: Clinical Biochemistry of Domestic Animals, 4th ed. (Kaneko, J. J. ed.), Academic Press, San Diego.

4. Carlson, G. P. 1989. pp. 543-575. In: Clinical Biochemistry of Domestic Animals, 4th ed. (Kaneko, J. J. ed.), Academic Press, San Diego.

5. Cornelius, C. E. 1989. pp. 364-397. In: Clinical Biochemistry of Domestic Animals, 4th ed. (Kaneko, J. J. ed.), Academic Press, San Diego.

6. Ishihara, K., Kitagawa, H., Ojima, M., and Suganuma, Y. 1978. Jpn. J. Vet. Sci. 40: 525-537.

7. Kitagawa, H., Sasaki, Y., Ishihara, K., and Kawakami, M. 1991. Am. J. Vet. Res. 52: 121-132.

8. Kitagawa, H., Sasaki,Y., Mori, M., and Ishihara, K. 1987. Jpn. J. Vet. Sci. 49: 285-293.

9. Kitagawa, H., Yasuda, K., Kitoh, K., and Sasaki, Y. 1994. J. Vet.Med. Sci. 56: 861-867.

10. Rawlings, C. A. 1986. pp. 175-207. In: Heartworm Disease in Dogs and Cats (Rawlings, C. A. ed.), WB Saunders, Philadelphia. 